\title{
Cooked meat products made of coarsely ground pork: the main bacterial strains of bacterial flora, their heat resistance and effect on spoilage
}

\author{
Esko PetäJÄ and Eero PuOlanNe
}

\begin{abstract}
PETÄJÄ, E. \& PuOLANNE, E. 1993. Cooked meat products made of coarsely ground pork: the main bacterial strains of bacterial flora, their heat resistance and effect on spoilage. Agric. Sci. Finl. 2: 413-421. (Dept. Food Technol., Meat Sect., FIN-00014 University of Helsinki, Finland.)
\end{abstract}

\begin{abstract}
This study was conducted to investigate the bacterial flora of the surface layer and the core of meat products made of coarsely ground pork at the moment of spoilage when stored at $7^{\circ} \mathrm{C}$ or $4^{\circ} \mathrm{C}$. The dominating strains were isolated, their heat resistance was studied in APT-broth, on APT-agar and in coarsely ground cured pork, and their growth after heating and effect on spoilage were followed in coarsely ground cured pork.

The first signs of spoilage appeared in the surface layer of the products. The strains were coccoid lactic acid bacteria with counts ranging from 3.5 to $7.8 \log$ cfu (colony forming units)/g. They survived only accidentally after heating for 15 minutes at $72^{\circ} \mathrm{C}$ in APT-broth. The core of the products contained only coccoid lactic acid bacteria or only pseudomonads or both as the main bacterial strains. The counts ranged from 2.6 to $6.0 \mathrm{log} \mathrm{cfu} / \mathrm{g}$. Most of the strains isolated from the core survived after heating for 30 minutes at $72^{\circ} \mathrm{C}$ in APT-broth in at least three tests out of six. The most noticeable result of the study was the occurence of heat-resistant pseudomonads in the core. It must be pointed out that all pseudomonads found survived after heating for 60 minutes at $72^{\circ} \mathrm{C}$ in APT-broth, and often after heating for 15 minutes at $72^{\circ} \mathrm{C}$ in coarsely ground cured pork (core $72^{\circ} \mathrm{C}$ ). The cfu number of the two most heat-resistant streptococcus strains decreased only $1 \log$ unit over 15 minutes at $72^{\circ} \mathrm{C}$ in coarsely ground cured pork. The numbers of inoculated pseudomonads decreased but those of streptococci rose by a maximum of $1 \log$ unit when the experimental porks were kept at $4^{\circ} \mathrm{C}$ after heating. This indicates that streptococci and pseudomonads probably do not constitute a serious spoilage factor in cooked meat products, but spoilage is generally effected by bacteria which have contaminated the surface layer of the products after heat treatment.
\end{abstract}

Key words: keepability, spoilage, cooked meat, heat resistance

\section{Introduction}

The manufacture and consumption of food products made of coarsely ground meat has grown over the last 10 years in Finland. These products sometimes spoil quite quickly so that not only the surface layer but also the core is spoiled. There is not much information available on the keeping times or the microbial flora of these kinds of products, or about whether the bacteria which can survive heat treatment in the core spoil the product. These products can be assumed to resemble bologna-type cooked sausages and luncheon meat in many respects. In these products high bacterial counts may be found 
although the products would not always have spoiled. PARADIS and STILES (1978) have found $60 \%$ of commercial bologna type sausages contain bacteria over $10^{6} \mathrm{cfu} / \mathrm{g}$. According to ALLEN and FOSTER (1960) and HILL et al. (1976), 4-week-old bolognas contain over $10^{7}$ bacteria/g. DurTSCHAEVER (1977) reported over $10^{6}$ bacteria/g in $50 \%$ of commercial luncheon meats and HILL et al. (1976) found that $71 \%$ of luncheon meats stored for 3 weeks at $4-7^{\circ} \mathrm{C}$ contained over $10^{6}$ bacteria/g. According to many scientists (REUTER 1969, MANTEL and BECK 1977, DAELMAN and HOOF 1975) lactobacilli are the biggest bacterial group in cooked meat products. However, DowDELL and BOARD (1968) and GARDNER (1966, 1968) report that Microbacterium thermosphactum is the most important bacterial group causing spoilage in cooked sausage. GARDNER (1966) also found that cooked sausage may contain gram-negative bacteria, pseudomonads and achromobacteria, although gram-negative bacteria are generally assumed to die during the processing of cooked meat products (HALlenbach and POTTER (1981) and PAlumbo et al. (1974).

The purpose of this study was to find out the main bacterial types in the surface layer and core of cooked meat products made of coarsely ground pork, their survival after heat treatment in APTbroth, on APT-agar, and in coarsely ground cured pork, as well as their growth after heating and their effect on spoilage during storage in coarsely ground cured pork. Various methods were used since heat resistance is known to vary in different media.

\section{Material and methods}

\section{Product samples}

Seven samples of coarsely ground pork products were received directly from the manufacturers. The samples were 2-4 weeks old and they were kept at $4^{\circ} \mathrm{C}$ and $7^{\circ} \mathrm{C}$ up to the moment when the first signs of spoilage, smell and/or slime, were detected. Different samples were investigated for the two temperatures. At the moment when the first signs of spoilage appeared the samples were examined microbiologically.

\section{Microbiological examination of product samples}

The product was peeled and the surface layer sample was taken aseptically at 1-2 mm in thickness. The core sample was taken from the centre of product after cutting the product in two parts so that nothing came into contact with the sampling area. The following examinations were made:

- Total count of bacteria on plate count agar (Difco $0479,2-4 \mathrm{~d}$ at $30^{\circ} \mathrm{C}$ ), on APT-agar (Merck 10453, $3 \mathrm{~d}$ at $30^{\circ} \mathrm{C}$ ) and on blood agar (Orion, Espoo, Finland, $2 \mathrm{~d}$ at $37^{\circ} \mathrm{C}$ ). Because the bacteria to be counted may not grow in all media, three different agars for aerobic total plate count were used to ensure the growth of the dominating strains.

- Total count of anaerobic bacteria on SPS-agar (Merck 10235, $2 \mathrm{~d}$ at $37^{\circ} \mathrm{C}$ in anaerobic jar).

- Number of lactic acid bacteria on Rogosa-agar (Merck 5463, 4 d at $30^{\circ} \mathrm{C}$ ).

- Number of Brochothrix thermosphacta on STAA-agar (GARDNER 1966, $2 \mathrm{~d}$ at $22^{\circ} \mathrm{C}$ ).

- Number of staphylococci and micrococci on Baird-Parker-agar (Lab 85 and X085, 2 d at $37^{\circ} \mathrm{C}$ ).

- Number of coliforms on VRB-agar (Lab 31, 1 d at $\left.37^{\circ} \mathrm{C}\right)$.

The results were tested by variance analysis (Epistat program) in relation to storage temperature and surface layer and core.

\section{Isolation of the main bacterial types}

The surface layer and core of all product samples contained only a few strains in high numbers, and these were isolated. The main colonies were selected from the APT-agar dishes on which the samples had been plated. The dishes with the highest dilution were used. The colonies to be isolated were transferred to APT-agar and incubated for 2 
days at $30^{\circ} \mathrm{C}$. One typical colony of each strain was removed to APT-agar for storing the culture.

\section{Survival of the isolated strains after heating on solid and in liquid medium}

\section{Solid medium}

The survival of the strains after heating on a solid medium was studied with a Gradiplate W10-temperature-gradient incubator (Biodata Oy, Helsinki, Finland) with which it is possible to achieve a stepless temperature gradient within a range of 0 $10^{\circ} \mathrm{C}$. The operating principle is as follows: The bacteria are grown in cuvettes of $65 * 98 * 12 \mathrm{~mm}$, into which the agar is poured. The limit temperature for growth or survival is determined by measuring the distance of the growth limit from the lower temperature sensor and by calculating the respective temperature. The survival of the strains was investigated by growing them on APT-agar (Merck 10453 ) for 30 minutes at a temperature range of 50 $-70^{\circ} \mathrm{C}$. The inoculation was carried out by rolling a drop $(0.05 \mathrm{ml})$ of APT-broth culture onto the surface of the agar. Two strains were inoculated in the same cuvette. The 18-hour-old APT-broth culture was used for inoculation. Table 2 shows the ranges of inoculated cell count. Three determinations were made for each strain.

\section{Liquid medium}

The survival of the strains after heating in APTbroth at $72^{\circ} \mathrm{C}$ was investigated side by side with the experiments on solid medium. The $5 \mathrm{ml}$ APT broth was heated in a test tube to $72^{\circ} \mathrm{C}$ and inoculated with $0.05 \mathrm{ml}$ of 18-hour-old APT-broth culture. The ranges of the inoculated cell counts are presented in Table 2. Different tubes were prepared for each heating period and temperature. The inoculated test tubes were heated for 15, 30, 60, 90 and 120 minutes. After heat treatment they were incubated at $30^{\circ} \mathrm{C}$ for 2 days and the growth (turbid broth) was recorded. Six experiments were made for each strain.

\section{Survival of some isolated Pseudomonas and Streptococcus strains after heating in coarsely ground cured pork}

The survival of four Pseudomonas strains ( $1 \mathrm{~b}_{2}, 4 \mathrm{~b}$, $\left.6 \mathrm{~b}, 7 \mathrm{~b}_{2}\right)$ and two Streptococcus strains $\left(3 \mathrm{~b}_{1}, 7 \mathrm{~b}_{1}\right)$ was also examined in coarsely ground cured pork after heating at $72^{\circ} \mathrm{C}$. One experimental batch contained $150 \mathrm{~g}$ pork, $0.67 \mathrm{~g}$ glucose and $15 \mathrm{~g}$ water. The following additives were used: $\mathrm{NaCl}(2 \%)$, $\mathrm{NaNO}_{2}(0.012 \%)$, phosphates $\left(0.15 \% \mathrm{P}_{2} \mathrm{O}_{5}\right)$ and Na-ascorbate $(0.04 \%)$. The bacterial inoculum was added as APT-broth culture $(15 \mathrm{ml})$. The target number of colony forming units (cfu) in the inoculum was $10^{7} / \mathrm{g}$ meat. Control batches were made without bacterial inoculum. Instead, $15 \mathrm{ml}$ of water was added to the control batch. The coarse grinding of the meat and mixing of additives and bacteria were done in a Moulinex mixer (Moulinex, France) to a particle size of $0.5-1 \mathrm{~cm}$ (diameter).

Both experimental and control meat batches were packed in the $10 \mathrm{ml}$ glass tubes in which they were heated. Different tubes were prepared for each heating period. The pseudomonas tubes were heated in a water bath for 5,15 and 30 minutes after the temperature had been raised to $72^{\circ} \mathrm{C}$. The respective heating periods for Streptococcus 3 $\mathrm{b}_{1}$ tubes were 0.5, 2, 5 , and 15 minutes and for Streptococcus $7 \mathrm{~b}_{1}$ tubes $0.5,2,5,15,30$ and 60 minutes. After heating the tubes were cooled for 10 minutes at $10^{\circ} \mathrm{C}$ in a water bath and for 1 hour at $22^{\circ} \mathrm{C}$. The following microbiological determinations were made for the non-heated and heated coarsely ground meats, as well as for the meats heated for 5 minutes and stored for $2-3$ weeks at $6^{\circ} \mathrm{C}$ : total plate count on APT-agar, the number of pseudomonads on GSP-agar, staphylococci and micrococci on Baird-Parker-agar, lactic acid bacteria on Rogosaagar, and Brochothrix thermosphacta on STAAagar. The manufacturers of the media as well as the incubations were the same as those in the microbiological studies of the meat product samples.

The number of colony forming units of the inoculums was determined on APT-agar by incubating for 2 days at $30^{\circ} \mathrm{C}$. The survival of the inoculums after heating in APT-broth at $72^{\circ} \mathrm{C}(0.05 \mathrm{ml}$ in $5 \mathrm{ml}$ APT-broth) was also tested side by side with 
Table 1. Bacterial flora of cooked meat products made of coarsely ground pork at the moment of spoilage. The bacterial numbers are presented as logarithms of colony forming units $(\mathrm{cfu}) / \mathrm{g}$.

\begin{tabular}{|c|c|c|c|c|c|c|c|c|}
\hline \multirow[t]{3}{*}{ Storage temperature } & \multicolumn{4}{|c|}{$4^{\circ} \mathrm{C}$} & \multicolumn{4}{|c|}{$7^{\circ} \mathrm{C}$} \\
\hline & \multicolumn{2}{|c|}{ Surface layer } & \multicolumn{2}{|c|}{ Core } & \multicolumn{2}{|c|}{ Surface layer } & \multicolumn{2}{|c|}{ Core } \\
\hline & $\mathrm{X}$ & R & $\mathrm{X}$ & R & $\mathrm{x}$ & R & $\mathrm{X}$ & $\mathbf{R}$ \\
\hline \multicolumn{9}{|l|}{ Total plate count } \\
\hline -Plate count agar & $7.0 \mathrm{~A}$ & $4.9-7.8$ & $5.5 \mathrm{~B}$ & $5.2-5.9$ & $6.0 \mathrm{AB}$ & $4.2-7.5$ & $3.6 \mathrm{C}$ & $2.6-4.7$ \\
\hline -APTS-agar & $7.3 \mathrm{~A}$ & $4.9-8.5$ & $5.3 \mathrm{~B}$ & $4.6-5.7$ & $6.2 \mathrm{AB}$ & $4.6-7.7$ & $4.3 \mathrm{C}$ & $3.0-6.6$ \\
\hline -Blood agar & $6.4 \mathrm{~A}$ & $5.0-7-7$ & $5.2 \mathrm{~B}$ & $4.6-6.0$ & 5.7AB & $3.5-6.9$ & $3.4 \mathrm{C}$ & $2.5-4.4$ \\
\hline Total count of anaerobes & $5.4 \mathrm{~A}$ & $3.8-6.3$ & 3.9B & $2.7-4.8$ & $2.5 \mathrm{AB}$ & $1.0-4.8$ & $1.3 \mathrm{C}$ & $1.0-2.7$ \\
\hline Lactic acid bacteria & $4.8 \mathrm{~A}$ & $1.0-6.7$ & $2.1 \mathrm{~B}$ & $1.0-3.4$ & 4.8AC & 2.9-6.9 & 2.9ABC & $1.0-4.6$ \\
\hline Brochothrix thermosphacta & & $<2.0-6.6$ & & $<2.0-4.2$ & 4.3 & $2.7-5.3$ & & $<2.0-3.5$ \\
\hline Staphylococci + micrococci & 2.6 & 2.3-3.0 & & $<2.0-2.9$ & & $<2.0-5.7$ & & $<2.0-4.8$ \\
\hline Coliforms & & $<1.0$ & & $<1.0-1.3$ & & $<1.0$ & & $<1.0$ \\
\hline
\end{tabular}

the coarsely ground pork experiments. Thermal resistance experiments with coarsely ground pork were made three times for Pseudomonas strains and four times for Streptococcus strains.

\section{Results and discussion}

\section{Bacterial flora in the product samples}

The samples stored at $4^{\circ} \mathrm{C}$ were 7 - 10 weeks old and the samples stored at $7^{\circ} \mathrm{C} 4$ weeks old at the moment of spoilage. Only the surface layer showed signs of spoilage. The total number of aerobically growing bacteria in the surface layer ranged from 3.5 to $8.5 \log$ cfu (colony forming units)/g at the moment of spoilage (Table 1). At the moment of spoilage the core of the products contained $4.6-6.0$ $\log \mathrm{cfu} / \mathrm{g}$ when the products had been stored at $4^{\circ} \mathrm{C}$ and $2.5-6.6 \log \mathrm{cfu} / \mathrm{g}$ when they had been stored at $7^{\circ} \mathrm{C}$. The mean of bacterial counts at $7^{\circ} \mathrm{C}$ was also significantly lower $(\mathrm{p}<0.05)$ than at $4^{\circ} \mathrm{C}$. The means of the bacterial counts both at $7^{\circ} \mathrm{C}$ and at $4^{\circ} \mathrm{C}$ were significantly lower $(\mathrm{p}<0.05)$ in the core than in the surface layer. KORKEALA and LinDROTH(1987) have previously also shown that the core of ring sausage contains less bacteria than the surface layer.
The counts for anaerobically growing bacteria ranged from 1.0 to $6.3 \mathrm{log} \mathrm{cfu} / \mathrm{g}$ the counts being higher $(\mathrm{p}<0.05)$ in the surface layer than in the core of the product, and also higher $(\mathrm{p}<0.05)$ after storing at $4^{\circ} \mathrm{C}$ than after storing at $7^{\circ} \mathrm{C}$ (Table 1). The number of lactic acid bacteria growing on Rogosaagar ranged from 1.0 to $7.0 \mathrm{log} \mathrm{cfu} / \mathrm{g}$, and the surface layer contained significantly $(\mathrm{p}<0.05)$ higher counts than the core at $4^{\circ} \mathrm{C}$. Most samples contained Brochothrix thermosphacta and staphylococci/micrococci. Their counts were also higher in the surface layer than in the core of the products. Apart from one core sample, none of the samples contained coliforms over $1.0 \mathrm{log} \mathrm{cfu} / \mathrm{g}$.

Lactic acid bacteria growing on Rogosa-agar, Brochothrix thermosphacta, staphylococci/micrococci or anaerobically growing bacteria were not found to form the main bacterial types of the bacterial flora of the products. However, the bacterial flora of the product samples contained 1 - 3 main bacterial types which grew on the APT-agar.

\section{Isolated bacteria}

Bacterial strains representing the main bacterial types of the flora were isolated both from the surface layer (12 strains) and the core (12 strains) of 
Table 2. Main bacterial strains of surface layer (a series) and core (b series) of cooked meat products made of coarsely ground pork, their survival after heat treatment at $72{ }^{\circ} \mathrm{C}$ in APT-broth and their highest survival temperature on APT-agar (Gradiplate method).

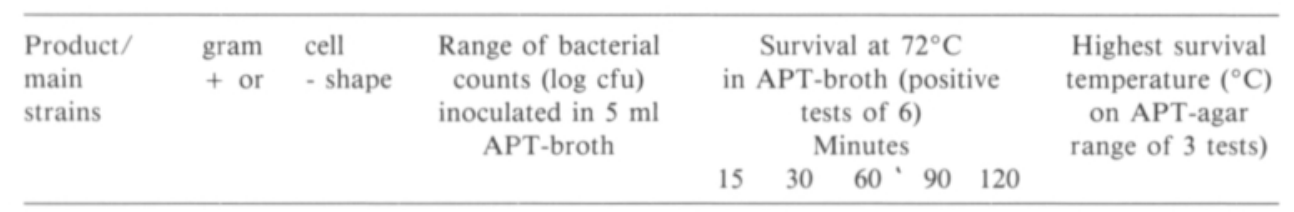

\begin{tabular}{|c|c|c|c|c|c|c|c|c|c|}
\hline \multicolumn{10}{|l|}{ a series } \\
\hline $1 / 1$ & + & coccob. & $6.1-6.8$ & 2 & 0 & 0 & 0 & 0 & $<45.5-49.1$ \\
\hline $1 / 2$ & + & coccob. & $7.0-7.5$ & 2 & 0 & 1 & 1 & 0 & $<46.4-52.9$ \\
\hline $2 / 1$ & + & coccob. & $7.3-7.4$ & 1 & 0 & 0 & 0 & 0 & $<46.2-51.1$ \\
\hline $2 / 2$ & + & coccob. & $7.5-8.2$ & 1 & 0 & 0 & 0 & 0 & 48.8 (1 test) \\
\hline $3 / 1$ & + & coccob. & $7.4-7.7$ & 0 & 0 & 0 & 0 & 0 & $47.4-49.0$ \\
\hline $3 / 2$ & + & coccob. & $7.5-8.3$ & 1 & 0 & 1 & 0 & 0 & $<45.5$ (1 test $)$ \\
\hline $3 / 3$ & + & cocci & $7.2-8.2$ & 0 & 0 & 0 & 0 & 0 & $47.3-49.1$ \\
\hline $4 / 1$ & + & cocci & $6.6-8.2$ & 2 & 1 & 0 & 0 & 0 & $<46.2-52.6$ \\
\hline $4 / 2$ & + & coccob. & $4.8-7.3$ & 1 & 0 & 0 & 0 & 0 & 55.3-58.2 \\
\hline $5 / 1$ & + & cocci & $3.7-6.2$ & 0 & 0 & 0 & 0 & 0 & $47.3-47.3$ \\
\hline $7 / 1$ & + & cocci & $5.7-7.2$ & 0 & 0 & 0 & 0 & 0 & $48.1-50.2$ \\
\hline $7 / 2$ & + & coccob. & $4.2-6.8$ & 0 & 0 & 0 & 0 & 0 & $47.8-55.0$ \\
\hline \multicolumn{10}{|l|}{ b series } \\
\hline $1 / 1$ & + & cocci & $6.5-7.1$ & 3 & 2 & 0 & 0 & 1 & $49.0-50.8$ \\
\hline $1 / 2(1 b 2)$ & - & rods & $6.8-6.9$ & 6 & 6 & 5 & 5 & 4 & 48.5-52.7 \\
\hline $2 / 1$ & + & cocci & $6.0-7.5$ & 3 & 2 & 0 & 0 & 0 & $<45.5$ (1 test) \\
\hline $2 / 2$ & + & cocci & $6.0-7.9$ & 5 & 4 & 0 & 0 & 0 & $46.8-51.3$ \\
\hline $3 / 1$ & + & cocci & $5.7-7.4$ & 6 & 6 & 6 & 5 & 2 & $50.3-56.6$ \\
\hline $3 / 2$ & + & cocci & $6.9-8.2$ & 5 & 4 & 0 & 0 & 0 & $<46.4$ (1 test) \\
\hline $3 / 3$ & + & cocci & $5.9-7.1$ & 1 & 1 & 2 & 2 & 2 & $48.5-50.3$ \\
\hline $4 / 1(4 b)$ & - & rods & $7.2-7.8$ & 6 & 4 & 3 & 2 & 0 & $50.5-58.9$ \\
\hline $5 / 1$ & - & rods & $6.1-6.9$ & 2 & 2 & 2 & 0 & 0 & $51.0-60.0$ \\
\hline $6 / 1(6 b)$ & - & rods & $6.9-8.2$ & 4 & 3 & 2 & 2 & 0 & $50.1-56.7$ \\
\hline $7 / 1$ & + & cocci & $7.7-7.9$ & 6 & 6 & 6 & 6 & 0 & $54.8-60.6$ \\
\hline $7 / 2$ (7b2) & - & rods & $6.5-7.1$ & 3 & 4 & 3 & 3 & 3 & $58.8-62.2$ \\
\hline
\end{tabular}

the products (Table 2). The strains isolated from the surface layer of the products were gram-positive cocci or coccibacilli also growing in chains. The core of two products also contained gram-positive cocci as the main bacterial types (5 pcs.), which were isolated. The core of two products contained gram-positive coccus and gram-negative rod as the main bacterial strains, whereas the core of three products contained only gram-negative rod as a main strain. These 7 strains were also isolated.

The gram-positive coccus strains isolated were of the same type of lactic acid bacteria as those found by KORKEALA et al. (1988) to be the main spoilage organisms in cooked sausages. Five strains also formed slime on APTS-agar (APT-agar + $1 \%$ saccharose). The two most heat-resistant strains proved to be streptococci. It must be pointed out that the cores of the products contained gramnegative rods, although gram-negative bacteria are generally destroyed by heat treatment (HALLENBACH and POTTER 1981, PALUMBo et al. 1974). However, GARDNER (1966) also reports that cooked sausage may contain pseudomonads and achromobacteria. The gram-negative rod strains isolated were oxidative and they were, therefore, regarded as pseudomonads. They also grew on GSP-Pseudomonas-agar. 
Table 3. Survival of some Pseudomonas strains after heat treatment at $72^{\circ} \mathrm{C}$ in APT-broth and in coarsely ground cured and cooked pork ( 3 test series). The strains were isolated from the core of cooked meat products made of coarsely ground pork.

\begin{tabular}{|c|c|c|c|c|c|c|c|c|c|c|c|}
\hline \multirow[t]{3}{*}{ Strain } & \multirow{3}{*}{$\begin{array}{l}\text { Range of bacterial } \\
\text { counts (log cfu) } \\
\text { inoculated in } 5 \mathrm{ml} \\
\text { APT-broth }\end{array}$} & \multicolumn{5}{|c|}{$\begin{array}{c}\text { Survival at } 72^{\circ} \mathrm{C} \\
\text { in APT-broth } \\
\text { (postive tests of 6) }\end{array}$} & \multirow[t]{3}{*}{$\begin{array}{l}\text { Range of bacterial } \\
\text { counts (log cfu/g) } \\
\text { inoculated in pork }\end{array}$} & \multicolumn{4}{|c|}{$\begin{array}{c}\text { Survival at } 72^{\circ} \mathrm{C} \\
\text { in coarsely ground } \\
\text { pork }(\log \mathrm{cfu} / \mathrm{g})\end{array}$} \\
\hline & & \multicolumn{5}{|c|}{ Minutes } & & \multicolumn{4}{|c|}{ Minutes } \\
\hline & & 5 & 15 & 30 & 60 & 90 & & 0 & 5 & 15 & 30 \\
\hline $1 b_{2}$ & $6.8-8.7$ & - & 4 & 4 & 4 & 4 & $7.1-8.0$ & 7.0 & 1) & 1 & 2 \\
\hline $4 b$ & $6.7-7.8$ & 5 & 4 & 3 & 4 & 2 & $7.0-7.2$ & 6.0 & 1 & 1 & 2 \\
\hline $6 b$ & $6.4-7-1$ & 6 & 4 & 4 & 4 & 2 & $7.4-7.7$ & 5.8 & 2 & 2 & 0 \\
\hline $7 b_{2}$ & $7.3-8.2$ & 6 & 6 & 4 & 5 & 2 & $7.6-8.5$ & 7.2 & 3.4 & 3.6 & 2 \\
\hline
\end{tabular}

1) Number of samples containing over $100 \mathrm{cfu} / \mathrm{g}$. Total number of samples $=3$.

\section{Survival of isolated bacterial strains after heat treatment in APT-broth and on APT-agar}

Seven strains from the surface layers survived after heating for 15 minutes at $72^{\circ} \mathrm{C}$ in either one or two of the six tests conducted (Table 2). Only one surface layer strain survived after heating on APT-agar at temperatures over $55^{\circ} \mathrm{C}$. The highest survival temperatures of most surface layer strains on APTagar varied around $50^{\circ} \mathrm{C}$.

Most of the strains isolated from the core of coarsely ground pork products survived after heating for 30 minutes at $72^{\circ} \mathrm{C}$ in APT-broth in at least three of the six tests (Table 2). Two gram-positive cocci and one gram-negative rod survived after heating for 30 minutes at $72^{\circ} \mathrm{C}$ in all six tests. These three strains also survived after heating for 90 minutes in at least five of the tests. It is noteworthy that all gram-negative rods isolated from the core of coarsely ground pork products were heat-resistant to the extent that all of them survived after heating for 60 minutes at $72^{\circ} \mathrm{C}$ in APT-broth. The isolated strains survived heating on APT-agar at distinctly lower temperatures than after heating in APTbroth. Only three strains exhibited the highest survival temperature of over $60^{\circ} \mathrm{C}$ in some of the experiments.

\section{Survival of four isolated Pseudomonas strains after heating at $72^{\circ} \mathrm{C}$ in coarsely ground cured pork}

Of the Pseudomonas strains isolated in this study from the core of the cooked products made of coarsely ground pork, strain $7 \mathrm{~b}_{2}$ survived best after heating in coarsely ground cured pork (Table 3 ). The mean number of colony forming units decreased from $\log 7.2 / \mathrm{g}$ to $\log 3.6 / \mathrm{g}$ during heating for 15 minutes. After heating for 30 minutes inoculated pseudomonads were found in two of the three tests over $\log 2.0 \mathrm{cfu} / \mathrm{g}$. After heating strains $1 \mathrm{~b}_{2}, 4 \mathrm{~b}$ and $6 \mathrm{~b}$ in coarsely ground cured pork for 15 minutes each strain were found over $\log 2.0 \mathrm{cfu} / \mathrm{g}$ in 1 - 2 tests of the three.

The total plate counts of bacteria in the heattreated coarsely ground experimental porks ranged between $\log 3.1$ and $5.6 \mathrm{cfu} / \mathrm{g}$. The control porks (not inoculated) contained pseudomonads and staphylococci/micrococci over $2.0 \mathrm{cfu} / \mathrm{g}$ only accidentally. They did not contain lactic acid bacteria over $\log 1.0 \mathrm{cfu} / \mathrm{g}$ or Brochothrix thermosphacta over $\log 2.0 \mathrm{cfu} / \mathrm{g}$. The non-heated coarsely ground, cured pork did not exceed these values either.

When the inoculated pork samples which had been heated for 5 minutes at $72^{\circ} \mathrm{C}$ were incubated 
Table 4. Bacterial flora of coarsely ground cured pork inoculated with four Pseudomonas strains after heating for 5 minutes at $72^{\circ} \mathrm{C}$ and incubating for 2 days at $30^{\circ} \mathrm{C}$ or $2-3$ weeks at $4^{\circ} \mathrm{C}$ ( 3 test series).

\begin{tabular}{|c|c|c|c|c|c|c|c|c|c|c|c|c|}
\hline & \multicolumn{4}{|c|}{$\begin{array}{c}\text { After heating } \\
\text { Strains }\end{array}$} & \multicolumn{4}{|c|}{$\begin{array}{c}2 \text { days at } 30^{\circ} \mathrm{C} \\
\text { Strains }\end{array}$} & \multicolumn{4}{|c|}{$\begin{array}{c}\text { 2-3 weeks at } 4^{\circ} \mathrm{C} \\
\text { Stains }\end{array}$} \\
\hline & $1 b_{2}$ & $4 \mathrm{~b}$ & $6 b$ & $7 b_{2}$ & $1 b_{2}$ & $4 b$ & $6 \mathrm{~b}$ & $7 b_{2}$ & $1 b_{2}$ & $4 b$ & $6 b$ & $7 b_{2}$ \\
\hline \multirow[t]{2}{*}{ Total plate count, APT-agar } & 1) $\times 4.1$ & 4.4 & 4.9 & 5.1 & 5.3 & 6.4 & 6.3 & 5.2 & 5.2 & 5.3 & 4.2 & 6.8 \\
\hline & s 0.8 & 1.4 & 0.7 & 0.1 & 1.0 & 1.8 & 1.5 & 0.1 & 0.4 & 1.8 & 0.3 & 2.0 \\
\hline \multirow[t]{2}{*}{ Pseudomonads, inoculated } & $\times 2.6$ & 2) 1 & 2 & 3.4 & 2 & 2 & 0 & 1 & 0 & 0 & 0 & 1 \\
\hline & s 0.9 & & & 1.3 & & & & & & & & \\
\hline Staphylococci + micrococci & 2 & 1 & 2 & - & 2 & 2 & 2 & 2 & 2 & 2 & 1 & 2 \\
\hline Lactic acid bacteria & 3) 0 & 0 & 0 & 0 & 0 & 0 & 0 & 0 & 0 & 0 & 0 & 0 \\
\hline
\end{tabular}

\footnotetext{
1) $\log \mathrm{cfu} / \mathrm{g}$

2) Number of samples containing over $100 \mathrm{cfu} / \mathrm{g}$. Total number of samples $=3$.

3) Number of samples containing over $10 \mathrm{cfu} / \mathrm{g}$.
}

for two days at $30^{\circ} \mathrm{C}$, the cfu number of strains $1 \mathrm{~b}_{2}$ and $4 \mathrm{~b}$ rose, whereas the cfu number of strains $6 \mathrm{~b}$ and $7 b_{2}$ decreased (Table 4 ). The total plate count for the porks rose to over log $6.0 \mathrm{cfu} / \mathrm{g}$.

When the inoculated pork samples, which had been heated for 5 minutes at $72^{\circ} \mathrm{C}$, were stored for 2 - 3 weeks at $6^{\circ} \mathrm{C}$, the numbers of all inoculated strains decreased (Table 4). The total plate count rose distinctly only in the tests in which strain $7 b_{2}$ was used.

The incubation experiments both at $30^{\circ} \mathrm{C}$ and at $6^{\circ} \mathrm{C}$ indicate that even if pseudomonads survive after heat treatment, they are probably not a very serious factor causing spoilage in cooked meat products made of coarsely ground meat or in cooked meat products in general.

\section{Survival of two most heat-resistant Streptococcus strains after heating at $72^{\circ} \mathrm{C}$ in coarsely ground cured pork}

The mean cfu numbers of the porks before heating were $6.8 \mathrm{log} \mathrm{cfu} / \mathrm{g}$ (strain $3 \mathrm{~b}_{1}$ ) and $7.6 \mathrm{log} \mathrm{cfu} / \mathrm{g}$ (strain $7 b_{1}$ ) (Table 5). The decrease for both strains was about $1 \log$ unit during heating for 2 minutes. The thermal death diminished when the heating was continued, and was about $2 \log$ units for $3 \mathrm{~b}_{1}$ and $0.5 \log$ unit for $7 b_{1}$ over the next $13 \mathrm{~min}$. Coarsely ground experimental porks contained staphylococci and micrococci over $2.0 \mathrm{log} \mathrm{cfu} / \mathrm{g}$ only accidentally, while pseudomonads and Brochothrix thermosphacta never exeeded $2.0 \mathrm{log}$ cfu/g. When the heat-treated and cooled experimental coarsely ground cured experimental porks were stored at $6^{\circ} \mathrm{C}$ for 2-3 weeks the cfu number of strain $3 b 1$ rose by 1 log unit and that of strain $7 b_{1}$ by $0.5 \log$ unit. However, these bacteria probably do not constitute a spoilage problem because their cfu number decreases by a few log units during cooking and rises only slightly during storage.

\section{Conclusion}

The core of the pork products were found to contain heat-resistant streptococci and pseudomonads as the main bacterial strains, but they were not the cause of spoilage of the products. The bacteria which contaminated the products after heat treatment caused the spoilage in the surface layer of the products. However, the reasons for eventual core spoilage were not found in this investigation. 
Table 5. Thermal death of Streptococcus strains $3 \mathrm{~b} 1$ and $7 \mathrm{~b} 1$ at $72^{\circ} \mathrm{C}$ in APT-broth (6 test series) and in coarsely ground cured pork (CCP) (4 test series).

\begin{tabular}{|c|c|c|c|c|c|c|c|c|c|}
\hline \multirow{3}{*}{$\begin{array}{l}\text { Heating } \\
\text { time, min }\end{array}$} & \multicolumn{5}{|c|}{$\mathrm{Cfu} / \mathrm{ml}$ in APT-broth } & \multicolumn{4}{|c|}{$\mathrm{Cfu} / \mathrm{g}$ in $\mathrm{CCP}$} \\
\hline & \multicolumn{3}{|c|}{$3 \mathrm{~b} 1$} & \multicolumn{2}{|c|}{$7 \mathrm{~b} 1$} & \multicolumn{2}{|c|}{$3 \mathrm{bl}$} & \multicolumn{2}{|c|}{$7 \mathrm{bl}$} \\
\hline & & $\mathrm{X}$ & s & $\mathrm{X}$ & s & $\mathrm{X}$ & s & $\mathrm{x}$ & s \\
\hline 0 & & 6.3 & 0.9 & 6.5 & 0.2 & 6.8 & 0.5 & 7.6 & 0.5 \\
\hline 0.5 & & 4.2 & 0.8 & 5.2 & 0.5 & 6.3 & 1.0 & & \\
\hline 1 & & 4.1 & 0.8 & 5.0 & 0.4 & & & & \\
\hline 1.5 & & 4.0 & 1.7 & 5.0 & 0.3 & & & & \\
\hline 2 & & 3.5 & 1.3 & 4.8 & 0.5 & 5.7 & 0.7 & 6.8 & 0.9 \\
\hline 5 & & 1.7 & 1.9 & 4.3 & 1.0 & 5.2 & 0.5 & 6.5 & 0.6 \\
\hline 15 & & 1.2 & 1.4 & 3.7 & 1.1 & 4.0 & 1.2 & 6.0 & 1.3 \\
\hline 30 & 1) & 4 & & 2.1 & 0.9 & & & 5.5 & 1.1 \\
\hline 60 & & 1 & & 2 & & & & 5.3 & 1.4 \\
\hline 120 & & 0 & & 1 & & & & & \\
\hline
\end{tabular}

$\mathrm{Cfu}=$ colony forming unit

$\mathrm{X}=$ mean of colony forming units

$\mathbf{s}=$ standard deviation of mean

1) Number of samples containing colony forming units

\section{References}

Allen, J. R. \& Foster, E. M. 1960. Spoilage of vacuumpacked sliced processed meats during refrigerated storage. Food Res. 25: 19-25. (Ref. Paradis \& Stiles 1978.)

DaElman, W. \& VAN HoOF, J. 1975. Einfluss des pH-Wertes, der Verwendung von Polyphosfat und der Lagerung auf die bakteriologische Beschaffenheit von Brühwurst und Brühwurstaufschnitt. Archiv für Lebensmittelhygienie 26: 213-217.

Dowdel., M. \& BoARD, R. 1968. A microbiological survey of British fresh sausage. J. Appl. Bacteriol. 31: 378-396.

Duitschaever, C. L. 1977. Bacteriological evaluation of some luncheon meats in Canadian retail market. J. Food Prot. 40: 382-384.

GARDNER, G. 1966. A selective medium for the enumeration of Microbacterium thermosphactum in meat and meat products. J. Appl. Bact. 29: 455-460.

- 1968. Effects of pasteurization or added sulphite on the microbiology of stored vacuum-packaged baconburgers. J. Appl. Bacteriol. 31: 462-478.

Hallenbach, C. H. \& Potter, N. N. 1981. Effects of nitrite and sorbate on bacterial populations in frankfurters and thuringer cervelat. J. Food Prot. 44: 341-346.

Hil., W. M., Reaume, J. \& Wilcox, J. C. 1976. Total plate count and sensory evaluation as measures of luncheon meat shelf life. J. Milk Food Techn. 39: 759-762.

Korkeala, H. \& Lindroth, S. 1987. Differences in microbiological growth in the surface layer and at the centre of vacuum-packed cooked ring sausage. Int. J. Food Micro- biol. 4: 105-110.

—, SuORTTI, T. \& MÄKEL Ä, P. 1988. Ropy slime formation in vacuum-packed cooked meat products caused by homofermentative lactobacilli and a Leuconostoc species. Int. J. Food Microbiol. 7: 339-347.

Mantel, T. \& BeCK, G. 1977. Zur microbiologischen Situation vorverpackter Brühwurst. Fleischwirtsch. 57: 245247.

Palumbo, S. A., Huhtanen, C. N. \& Smith, J.-L. 1974. Microbiology of frankfurter's process: Salmonella and natural aerobic flora. Appl. Microbiol. 27: 724-732.

Paradis, D. C. \& Stiles, M. E. 1978. A study of microbial quality of vacuum packaged sliced bologna. J. Food Prot. 10: 811-815.

REUTER, G. 1969. Untersuchungen zur Mikroflora von Vorverpackten Aufgeschnittenen Brüh- und Kochwursten. Proc. 15th Eur. Meet. Meat Res. Workers, Helsinki. p. 124-134.

\section{Manuscript received April 1993}

Esko Petäjä

Eero Puolanne

Department of Food Technology

Meat Section

FIN-00014 University of Helsinki, Finland 


\title{
SELOSTUS
}

\section{Keitettyjen karkeahienonnetusta lihasta valmistettujen lihavalmisteiden bakteeriflooran hallisevat bakteerikannat, niiden lämpöresistenssi ja vaikutus pilaantumiseen}

\author{
Esko PetäJÄ ja Eero PuOlanNe
}

Helsingin yliopisto

Keitettyjen karkeahienonnetusta lihasta valmistettujen lihavalmisteiden pintaosan ja sisäosan bakteeriflooraa tutkittiin pilaantumishetkellä, kun valmisteita oli säilytetty $7^{\circ} \mathrm{C}$ tai $4^{\circ} \mathrm{C}$ :ssa. Flooraa hallitsevat bakteerikannat eristettiin ja niiden lämpöresistenssiä tutkittiin APT-liemessä, APT-agarilla ja karkeahienonnetussa suolatussa sianlihassa.

Valmisteiden pintaosan bakteeriflooraa hallitsevat kannat olivat kokkimaisia maitohappobakteereja lukumäärien vaihdellessa vălillä 3,5-7,8 log pmy(pesäkkeen muodostava yksikkö)/g. Valmisteiden sisäosan bakteerifloora sisälsi valtaorganismeina kokkimaisia maitohappobakteereja, kokkimaisia maitohappobakteereja ja pseudomonadeja tai pseudomonadeja. Kaksi lämpöresisteintä maitohappobakteeria olivat streptokokkeja. Sisäosan bakteerien kokonaislukumäärät vaihtelivat välillä 2,5-6,0 log pmy/g.

Valmisteiden pintaosasta eristetyt bakteerikannat säilyivät lisääntymiskykyisinä vain satunnaisesti, kun niitä lämpökäsiteltiin 15 min $72^{\circ} \mathrm{C}$ :ssa APT-liemessä. Useimmat valmisteiden sisäosasta eristetyistä kannoista säilyivät lisääntymiskykyisinä vähintään kolmessa kokeessa kuudesta, kun niitä läm- pökäsiteltiin 30 min $72^{\circ} \mathrm{C}$ :ssa APT-liemessä. On merkille pantavaa, että kaikki sisäosasta eristetyt pseudomonadikannat säilyivät lisääntymiskykyisinä, kun niitä lämpökäsiteltiin 60 min $72^{\circ} \mathrm{C}$ :ssa APT-liemessä, ja usein, kun niitä lämpökäsiteltiin karkeahienonnetussa sianlihassa 5 min $72^{\circ} \mathrm{C}$ :ssa. Inokuloitujen pseudomonadien lukumäärä laski, kun lämpökäsiteltyjä koelihoja säilytettiin $4^{\circ} \mathrm{C}$ :ssa. Siten ne eivät todennäköisesti ole vakava pilaantumistekijä karkeahienonnetusta lihasta valmistetuissa lihavalmisteissa tai keitetyissä lihavalmisteissa yleensä.

Lämpöresisteimpien streptokokkien lukumäärä (pmy) laski APT-liemessä jyrkemmin kuin karkeahienonnetussa sianlihassa, jossa lasku oli noin yksi log-yksikkö 15 minuutissa. Kun lämpökäsiteltyjä karkeahienonnettuja ja suolattuja sianlihoja säilytettiin 4 viikkoa $4^{\circ} \mathrm{C}$ :ssa, streptokokkien lukumäärä nousi enintään yhden log-yksikön. Kuitenkin myöskään streptokokit eivăt aiheuttane pilaantumista, koska niiden lukumäärä laskee lämpökäsittelyn aikana selvästi ja nousee kylmävarastoinnin aikana vain vähän. 